\title{
Maataloudesta terveyttä ja hyvinvointia: hoivamaatalouden mahdollisuudet
}

\author{
Taina Lilja ${ }^{1}$, Anja Yli-Viikari ${ }^{1}$, Katariina Heikkilä ${ }^{2}$, Tapani Kivinen ${ }^{1}$, Anna Kirveennummi ${ }^{2,}$ Leena \\ Rantamäki-Lahtinen ${ }^{1}$ \\ ${ }^{1}$ MTT Taloustutkimus, 31600 Jokioinen, etunimi.sukunimi@mtt.fi \\ 2 Tulevaisuudentutkimuskeskus, etunimi.sukunimi@tukkk.fi
}

\section{Tiivistelmä}

Hoivamaatalous on yritystoiminnan muoto, joka on lähtenyt viime vuosina laajenemaan useissa Euroopan maissa. Hoivamaataloudessa hyödynnetään maatilan perinteisiä resursseja uudella tavalla: elintarvikkeiden sijaan tavoitteena on virkistys-, kuntoutus- ja kasvatuspalveluiden tuottaminen erilaisille asiakasryhmille. MTT:n ja Tulevaisuuden tutkimuskeskuksen tutkimushankkeessa "Palvelumaatalous maaseudun mahdollisuutena 2005-2007" selvitetään toimialan yritys- ja yhteiskuntataloudellisia reunaehtoja Suomessa käyttäen hyväksi suomalaisten edelläkävijäyritysten kokemuksia. Tulokset osoittavat, että hoivamaatalous saattaisi jatkossa tarjota erään toimeentulomahdollisuuden uutta tuotantomuotoa hakeville maatiloille. Näin varsinkin silloin kun yrittäjillä on jo ennestään sosiaali- ja terveydenhoitoalan kokemusta ja ammattitaitoa. Toimialan kasvua tukee sosiaali- ja terveydenhuoltopuolella meneillään oleva julkisten palveluiden yksityistäminen. Maaseutuyritysten kilpailuetuja, jotka perustuvat mm. luontoon, kotieläimiin ja kuntouttavaan työhön, hyödynnetään kuitenkin edelleen Suomessa varsin heikosti.

\section{Taustaa}

Maatilojen hoivayrittäjyys -hoivamaatalous- on lähtenyt laajenemaan useissa Euroopan maissa. Uudelle toimialalle luonteenomaiseen tapaan hoivamaatalouttakin luonnehtii kohderyhmien, terminologian ja rahoitusrakenteiden moninaisuus. Keskustelua on käyty "Farming for Health"käsitteen alaisuudessa, mutta myös "Green Care in Agriculture", "Social farming", "Care farming" ja "Farm as a classroom" ovat laajalti käytettyjä termejä. Hollannissa, Norjassa, Belgiassa ja Sveitsissä maatilat ovat pääosin yksityisiä perhetiloja, Italiassa sosiaalisia osuuskuntia ja Saksassa osa terveydenhoitolaitoksia.

Maatalous- ja puutarhatyöllä hoitolaitoksissa on Suomessakin perinteitä. Suuret laitokset kuten vanhainkodit, alkoholistiparantolat ja vankilat ovat aikaisemmin sijainneet maatiloilla. Myöhemmin laitosten maatilakytkennöistä on pyritty eroon. Huostaan otettujen lasten sijoittaminen maatiloilla asuviin perheisiin on tuttua samoin kuin lasten lomatoimintakin.

Suomalalaisilla maatiloilla sijaitsee tällä hetkellä noin pari sataa hoito- ja hoivapalvelua tarjoavaa yritystä. Ne ovat usein maaseudulla; maatiloilla tai niiden läheisyydessä sijaitsevia perhekoteja samoin kuin vanhusten ja mielenterveyskuntoutujien hoivakoteja. Viime vuosien aikana erityisesti ratsastusja puutarhaterapian sekä sosiaalipedagogisen hevostoiminnan tarjonta on lähtenyt selkeään kasvuun.

Uudistukset kunta- ja palvelurakenteissa samoin kuin palveluiden yksityistäminen ja yksilöllisten ratkaisujen hakeminen avaa uusia mahdollisuuksia toimialalle. Sosiaali- ja terveydenhuoltoalan palvelujen ostaminen yksityiseltä ja kolmannelta sektorilta on lisääntymässä, kun taas samanaikaisesti maatilojen määrä on vähenemässä ja monipuolisia resursseja kuten ammattitaitoa ja rakennuksia on jäämässä vajaakäytölle (Kaarakainen et al., Kansallinen projekti...2004). 
MTT:n ja Tulevaisuuden tutkimuskeskuksen hankkeessa "Maatilat maaseudun palvelutoiminnassa" tavoitteena on selvittää, millaisia liiketoimintamahdollisuuksia maatiloilla on tuottaa hoivapalveluita, joissa maaseutua ja maatilan toimintoja hyödynnetään resurssina palvelujen tuotannossa ja mitkä yhteiskunnalliset reunaehdot yhtäältä rajaavat ja toisaalta tukevat toimialan kehitystä.

Maatilan määritelmä on tutkimuksessa normaalia maatalouspoliittista määrittelyä laajempi. Määritelmä kattaa sekä maataloustuotantoa harjoittavat aktiivimaatilat että tuotannosta luopuneet tilat sekä maaseudulla sijaitsevat yritykset, joilla on käytössään maataloustuotannolle luonteenomaisia resursseja kuten viljely- tai puutarhamaata, kotieläimiä, viljelykasveja ja maataloustyötä. Hankkeen myötä maatalouden ja hoivapalveluiden välinen rajanveto ja yhteinen toiminta-alue tulee tarkentumaan.

Hoivayritykset voidaan (mm. Kaarakainen 2005) määritellä laajasti sellaiseksi sosiaali- ja terveydenhuoltoalan yritystoiminnaksi, joka käsittää eri-ikäisten ihmisten huolenpidon ja hoidon. Palveluja tarjoavat sekä yksityiset yritykset että erilaiset palveluja tarjoavat yhdistykset. Asiakaskunta kattaa laajan kirjon lapsia, nuoria, työikäisiä ja vanhuksia, joilla on erilaisia sosiaali- ja terveydenhuoltoalan ongelmia.

Hoiva- ja hyvinvointialan palveluyrittäjyys on verrattain uusi ilmiö, sillä vanhimmat alalla toimivat yritykset on perustettu 1980- ja 1990-lukujen taitteessa. Yrittäjyyden syntyä vauhditti 1990-luvun alussa koettu lama ja sen aiheuttama työttömyys sekä vuonna 1993 voimaan tullut valtionosuusuudistus. Sen ansiosta kunnat voivat ostaa palveluja myös julkisen sektorin ulkopuolelta.

Vuonna 2005 yksityisiä sosiaalipalveluja tarjosi 3550 toimipaikkaa, ja ala on ollut kovassa kasvussa. Tällä hetkellä yksityinen sektori tuottaa jo lähes neljänneksen kaikista sosiaalipalveluista (Stakes 2007).

\section{Aineisto ja menetelmät}

Tutkimuksen tärkeimpänä aineistona on viisi maaseudulla sijaitsevaa hoivapalveluyritystä, jotka omassa toiminnassaan ovat onnistuneet yhdistämään hoivatyön ja maaseudun. Aineiston laajuuden ja ja kattavuuden sijaan haluttiin kartoittaa tutkimuksen alla olevaa ilmiötä mahdollisimman monelta suunnalta. Mukaan valittiin niin vanhuksiin, päivähoitolapsiin, ongelmanuoriin kuin myös mielenterveyskuntoutujiin liittyviä hoivayrityksiä. Kohdeyrityksiä ei ollut helppo löytää, jolloin kriteerejä maatalouteen liittyviä kriteerejä jouduttiin loiventamaan ja ottamaan mukaan myös yritystoiminnan alkuvaiheessa olevia yrityksiä.

Caseyritykset ovat:

1. Vanhusten hoivakoti, joka sijaitsee viljanviljelyä ja koneurakointia harjoittavalla tilalla

2. Vanhusten hoivakoti, joka sijaitsee maaseutuympäristössä.

3. Mielenterveyskuntoutujien hoivakoti entisen kansakoulun tiloissa. Asiakkailla mahdollisuus työskennellä puutarhassa ja kanalassa ja suunnitteilla yhteistyötä lähistön maatilojen kanssa

4. Ratsastustalli, jossa yhtenä toimintamuotona on sosiaalipedagoginen hevostoiminta

5. Lastenpäiväkoti lypsykarjatilan yhteydessä.

Näiden lisäksi tutkimuksessa käytetään hyväksi 2004-2006 toteutetun maatiaishankkeen aineistoja yrityksistä, joissa oli samantyyppistä hoiva-alan yrittäjyyttä. Hoiva-ajan yrittäjyyttä koskevia yritysaineistoja täydennettiin maaseudulla toimineiden yrittäjien kokemuksia ja naapureiden suhtautumista kartoittaneilla haastatteluilla sekä viranomaistahojen puhelinhaastatteluilla. 
Tutkimusaineistoa kerättiin vuoden 2007 aikana tehtyjen yrityskäyntien ja haastattelujen avulla. Menetelminä olivat toiminnan ja miljöön havainnointi sekä teemahaastattelut. Havainnoinnin kautta hahmotettiin yrittäjän ja yrityksen asiakkaiden jokapäiväistä elinympäristöä ja sen merkitystä yrityksen/yrittäjän toiminnalle ja asiakkaiden elämänlaadulle.

Teemahaastattelujen avulla oli mahdollista tutustua yrityksen ja yrittäjän tilanteeseen ja taustaan. Laadullisen tutkimusotteen mukaisesti tavoitteena oli selvittää ennen kaikkea hoivayrittäjien omalle toiminnalleen antamien merkitysten moninaisuutta, ja niitä solmukohtia, vaikeuksia ja onnistumisen tilanteita, joita yrittäjä oli toiminnassaan kokenut. Keskustelun teemoina olivat mm. tilan ja yritystoiminnan vaiheet ja historia, yrityksen talous, maatila ja maaseutu resurssina yrityksen toiminnassa, asiakaskunta ja viranomaisyhteistyö, sosiaalinen ympäristö sekä yrityksen tulevaisuuden näkymät.

Tämän lisäksi tarkasteltiin yrityksen taloudellista tilaa sekä perehdyttiin viranomaisten vaatimuksiin rakentamisen suhteen mm. tutustumalla rakennuspiirustuksiin. Yritysvierailujen yhteydessä otettiin valokuvia ja haastattelut nauhoitettiin.

Yritysanalyysi tulee koostumaan kaikkiaan seuraavista osakokonaisuuksista, jotka tehdään monitieteisen tutkijaryhmän yhteisen keskustelun ja analyysin kautta:

1. Fyysisen toimintaympäristön rakennusten ja maiseman kuvauksesta, jossa yritysten fyysisiä vaatimuksia tarkastellaan nykyisen lainsäädännön ja toimintojen järjestämisen näkökulmasta. Havaintojen pohjalta laaditaan korjaus- ja muutosehdotukset pyrkien samalla tunnistamaan toimialaan liittyviä yleisiä fyysisen ympäristön edellytyksiä.

2. Liiketaloudellisen kilpailukyvyn arvioinnista, jossa yrityskohtaisen analyysin kautta haetaan toimialalle tyypillisiä liiketaloudellisia ominaispiirteitä.

3. Maatalouden, maaseudun ja hoiva-yrittäjyyden suhteen kuvauksesta, jossa selvitetään miten yritys tiedostaen tai tiedostamattaan tuotteistaa ympäristön ja historian kulttuurisista erityispiirteistä uudenlaisia kulttuurisia kokonaisuuksia.

Seuraavassa luvussa esitellään alustavia tuloksia tästä aineistosta. Lopulliset tulokset julkaistaan vuoden 2008 aikana MTT:n raporttisarjassa.

\section{Alustavat tulokset}

\section{Maataloudesta hoivayrittäjäksi - yrityksiä elämänkaaren eri vaiheissa}

Haastatellut yritykset toimivat elämänkaarensa eri vaiheissa. Perhekodissa oltiin vielä valmistelemassa alalla siirtymistä: remontti oli osittain kesken, lypsykarjasta oltiin parasta aikaa luopumassa ja ensimmäisiä asiakassuhteita kuntien sosiaalitoimiin oltiin rakentamassa. Päiväkoti ja entisen maatalousoppilaitoksen tiloihin perustettu hoivakoti olivat niin ikään aloittamassa vasta toista toimintavuottaan. Maatilalla sijaitseva vanhusten hoivakoti edusti sarjassa vakiintuneinta liiketoimintaa, joka oli lähtenyt liikkeelle jo 1990-luvun alkupuoliskolta. Täällä suunniteltiin jo yritystoiminnasta luopumista eläkkeelle siirtymisen vuoksi.

Takana olevan toiminta-ajan pituus vaikutti paljolti siihen, mitkä asiat yrityksissä olivat esillä. Ensimmäisinä vuosina luodaan yrityksen asiakassuhteet ja ne ovat monesti myös taloudellisesti tiukkaa aikaa. Aloitteleville yrityksille on niin ikään tyypillistä suuri vaihtelu asiakkaiden määrissä ja epävarmuus asiakkaiden riittämisestä. Ongelmana on erityisesti se, että tulot vaihtelevat voimakkaasti, kun taas toiminnan kustannukset työvoimavaltaisella hoiva-alalla ovat pysyvästi korkeat. 
Tavallisestikin palkkakustannukset ovat $60-70 \%$ kokonaisbudjetista, mutta saattavat vanhusten ja vammaisten hoitotyössä lähestyä jo 80 prosenttia.

Kaikissa esimerkkiyrityksissä oli käytössä vierasta työvoimaa ratsastusterapiatallia lukuun ottamatta. Yhteistä kaikille oli, päiväkotia lukuun ottamatta, toiminta omissa tiloissa. Päiväkoti erosi tästä joukosta siten, että se toimi maatilan päärakennuksen läheisyydessä sijaitsevissa vuokratuissa tiloissa, jotka omistaja oli remontoinut toimintaan sopivaksi.

\section{Kynnys yrittäjyyteen}

Hoivayrittäjyydelle maaseudulla on vähän toimintamalleja, joihin aloitteleva yrittäjä saattaisi tukeutua. Haastatellut yrittäjät olivatkin oman alansa edellä kävijöitä, jossa taustalla oli yrittäjän pitkäaikaisen unelman ja suunnitelman toteutuminen. Kriittisenä kynnyksenä oli monesti vaihe, jossa maatilalle oli tarpeen suunnitella uudenlaisia toimeentulon vaihtoehtoja. Perhekodin yrittäjäparin mukaan "...nykyaikana maatilat hakee tälläsia jotain vaihtoehtoja hyvin paljon..." Hoivayrittäjyys muodostui varteen otettavaksi vaihtoehdoksi, kun toisella yrittäjäpuolisoista - kaikissa näistä tapauksista naisella - oli sosiaali-, terveys tai kasvatusalan koulutusta ja työkokemusta. Sysäyksenä yritystoiminnalle saattoi myös olla harrastus kuten ratsastus tai lapsuudenkodin perinteet pitää kaupunkilaislapsia kesällä lomalla tai oma hoivaa tarvitseva omainen.

Näin oli esimerkiksi mielenterveyskuntoutujien hoivakodissa, joka lähti liikkeelle yrittäjäperheen omankohtaisesta tarpeesta. Toiminta lähti liikkeelle kun perheenjäsenelle ei löydetty sopivaa kuntoutuspaikkaa: "... näki mitä yhteiskunnasta puuttuu..." Terveydenhoitoalan ammattilaisena äiti osti vanhan kansakoulun, palkkasi ammattitaitoista työvoimaa ja alkoi pyörittää hoivakotia, jossa ensimmäinen asiakas oli oma poika. Hoito oli tuloksellista ja poika palasi normaaliin elämään. Hoivakotiin on kuitenkin riittänyt kuntoutusta tarvitsevia asiakkaita, jotka eivät ongelmiensa vuoksi pärjää vielä kotona. Vuosien varrella yrittäjä onkin havahtunut tällaisten kuntoutuspaikkojen tarpeeseen ja toivoo, että niitä perustettaisiin enemmänkin. Itse hän aikoo pitää oman yksikkönsä pienenä, koska niin se parhaiten vastaa tarkoitustaan. Yrityksen ensimmäinen palkattu työntekijä on kuitenkin perustanut vastaavan hoivayrityksen jo toisaalle.

Hoivayrityksen toiminnan kantavana voimana oli useinkin yrittäjän ja vetäjän omakohtainen vahva näkemys siitä, mitä vanhusten, lasten tms. "hyvä hoito" on ja miten sitä hoivayrityksessä tulee toteuttaa. Työntekijöitä rekrytoidessa onkin tärkeää pätevyyden lisäksi löytää yritykseen "sopivat" henkilöt, jotka jakavat samanlaisen arvomaailman - tai ainakin pystyvät omaksumaan yrittäjän arvomaailman.

\section{Ja kynnys pois yrittäjyydestä}

Yrittäjän eläkeiän lähestyessä on omat ongelmansa, sillä yritys on usein osa omaa yksityiselämää. Vieraan yrittäjän tulo esimerkiksi omassa pihapiirissä sijaitsevaan hoivayritykseen koettiin hankalaksi. Vanhuksia hoitavassa hoivakodissa lopettaminen oli tulossa joidenkin vuosien kuluessa ajankohtaiseksi. Yrittäjä oli sitä ennakoiden aloittanut siirtymävaiheen, jossa hän ei ottanut enää uusia pitkäaikaisasukkaita vaan tarjosi vähitellen vapautuvia hoitopaikkoja intervallihoitoa tarvitseville vanhuksille.

\section{Asiakkuudet - löytyykö laadulle maksajaa?}

Itse maksavia asiakkaita hoivayrityksissä oli melko vähän. Yleensä maksavana tahona olikin KELA tai kuntien viranomaiset. Lainsäädäntö velvoittaa kuntia järjestämään hoivapalvelut niitä tarvitseville, mutta kunnilla ei ole palvelujen tuottamisvelvoitetta. Kunnat ovat kasvavassa määrin alkaneet käyttämään myös yksityisten hoivayritysten tarjoamia palveluita, kun oma julkinen palvelutoiminta on osoittautunut riittämättömäksi. 
Yksityisten hoivakotien hintoja saatetaan kunnissa aluksi kauhistua, sillä pienimuotoisen hoivakodin tarjoama palvelu on erityyppistä kuin ison laitoksen. Asiakas, joka intensiivisemmällä hoidolla pystytään esimerkiksi mielenterveys- ja päihdepuolella kuntouttamaan, on pidemmän päälle kuitenkin suuri säästö kunnan budjettiin. Erikoissairaanhoidon asiakaspaikat ovat puolestaan noin viisinkertaisia verrattuna yksityiseen hoivakotiin.

Maaseudun hoivakodeissa halutaan "...tarjota vanhuksille jotain muuta vaihtoehtoo kun sen suuren osaston mikä tuola on...” ja ”...pyritään kunnioittamaan asiakkaiden omia yksilöllisiä tarpeita...”

Panostaminen yrityksen mainostamiseen ja tunnetuksi tekemiseen on erityisen tärkeää toiminnan alkuvaiheessa. Kokeneiden yrittäjien mukaan paikan ja toimintatapojen tunnettavuus, hoidon tuloksellisuus ja yrityksen hyvä maine ovat keskeisintä asiakassuhteiden luomisessa ja säilyttämisessä. Käytännössä markkinointi tarkoitti sähköposteja, neliväriesitteitä, puhelinsoittoja ja henkilökohtaisia vierailuja. Yrittäjät käyvät kertomassa yrityksen toiminnasta vanhustyön- ja sosiaalityönjohtajille ja sairaaloiden sosiaalityöntekijöille. Yhteydenpito on tiivistä; hoivakodin paikkatilanne voi vaihdella jopa päivittäin ja viikottain.

Tulevaisuutta yksityisissä maaseudun hoivakodeissa ei pelätä, vaikka työskentely vähän tunnetulla toimialalla onkin haasteellista pioneerityötä ja toiminnan vakiintuminen ottaa aikansa. Vanhusten määrä kasvaa kuitenkin lähitulevaisuudessa ja vähitellen kunnissa aletaan ymmärtää, että kaikkien palvelujen tuottaminen ei ole kustannustehokasta.

”...me tullaan tarvitsemaan yksityisiä hoivapalveluja jotta me pärjätään näitten ihmisten kanssa...”

Tulevaisuuden vanhukset ja hoivakotien asukkaat lähiomaisineen haluavat myös vaihtoehtoja, eivätkä tyydy samaan kuin aikaisemmilla vuosikymmenillä. Tämä ei tietenkään johda automaattisesti maaseudun hoivakotien suosioon, vaan maaseudulla sijaitsevien yritysten pitää pystyä tarjoamaan asiakkailleen jotain sellaista, mitä nämä ovat hakemassa.

”...tulevaisuuden vanhat ihmiset että heidän ei tarvi joka ikistä senttiä säästää pojalle tai pojanpojalle...tulevaisuuden vanhat haluukin käyttää elinaikana ansaitsemansa eurot omaan hyvinvointiin loppuelämä sellaista kun he on ajatellu...”

Sairaalat ovat alkaneet myös periä kunnilta ns. siirtoviivemaksua, sillä kalliilla sairaalapaikoilla ei kannata pitää asiakkaita, jotka eivät enää tarvitse sairaalahoitoa, mutta eivät toisaalta vielä tule selviytymään omassa kodissaankaan. Tämäkin tarjoaa mahdollisuuksia pienille hoiva-alan yrittäjille, jotka pystyvät tarjoamaan joustavan siirtymisen laitoshoidosta takaisiin itsenäiseen elämään.

Epävarmuutta yritysten tulevaisuuteen tuo sosiaali- ja terveydenhuoltoalalle tyypillinen riippuvuus valtiovallan päätöksistä. Säästöt esimerkiksi kuntoutuksessa vaikuttavat suoraan yksityisten hoivayritysten asiakasmääriin.

\section{Sosiaalinen ympäristö yrittäjän tukena - ja esteenä}

Maaseutuyrittäjä on tiiviisti sidoksissa lähiyhteisöönsä. Ympäröivän yhteisön ennakkoluuloisuus uutta toimintaa oli kohdattu kaikissa yrityksissä. Pahimmassa tapauksessa naapurusto oli estänyt lastensuojelulaitoksen perustamisen. Suhtautuminen vanhuksiin ja pieniin lapsiin oli yleensä myönteistä, kun taas mielenterveyskuntoutujia ja ongelmanuoria vierastettiin ja pelättiin häiriöitä. Myös yritystoimintaan myönteisesti suhtautuvat naapurit kertoivat joidenkin lähinaapureiden suvaitsemattomuudesta, asiakkaita leimaavista puheista sekä peräti muuttoaikeista. Aina eivät viranomaisetkaan osanneet suhtautua toimintaan luontevasti: 
”... jossain nuorisoporukka kävi ihmisten varastoja tyhjentelemässä niin poliisit tuli tänne pihalle aina ensimmäisenä...”, kertoo hoivakodin yrittäjä.

Viranomaisten vaihteleva suhtautuminen näkyy myös siinä, että ohjataanko oman kunnan asukkaita kunnassa sijaitsevaan hoivakotiin vai ei. Läheskään aina näin ei tapahtunut.

Toiminnan vakiintuessa kyläyhteisön suhtautuminen muuttui poikkeuksetta parempaan suuntaan, vaikkakin yhteydenpito saattoi edelleen olla vähäistä. Syyksi epäiltiin enemmänkin kateutta kuin pelkoa toimintaa kohtaan. Toisaalta yrittäjätkään ei välttämättä kaivanneet läheisempää yhteistyötä. Enemminkin koettiin tärkeäksi oma toimintavapaus ja se, että ympäristö ei hyljeksi.

Osa yrittäjistä toivoi kuitenkin asiakkailleen enemmän sosiaalisia kontakteja lähiympäristön kanssa, sillä normaali arkinen kanssakäynti tavallisten ihmisten kanssa saattaa olla tärkeä osa kuntoutumista, vuorovaikutustaitojen oppimista ja oman itseluottamuksen kasvattamista. Vanhusten hoivakodissa toivottiin ulkoilutusapua ja päiväkodin juhliin toivotettiin koko kylä tervetulleeksi. Päihde- ja mielenterveyskuntoutujien hoivapaikassa ideoitiin mahdollisuutta, että kodin asiakkaat kävisivät töissä naapuritilalla. Toisen hoivapaikan lähiympäristössä naapuruston maataloustöiden tekemistä oli jo kokeiltukin.

Todettiin, että naapureiden kanssa olisi hyvä käydä mahdollisimman avointa keskustelua, jotta tietämättömyyteen perustuvat puheet saataisiin estettyä.

\section{Työpaikkoja maaseudulle}

Työvoimavaltainen hoivayrittäjyys tarjoaa myös arvokkaita työpaikkoja maaseudulle, jossa oman alan työllistyminen on usein kiven takana. Yrittäjät tuntevat, että työntekijöillä on pienessä yrityksessä enemmän toimintavapautta kuin yhteiskunnan ylläpitämissä suurissa laitoksissa ja työpäivä on vaihteleva. Pienissä yrityksissä kukin hoitaa vuorollaan esimerkiksi ruuanvalmistamisen. Suuremmissa paikoissa ruokahuolto on, samoin kuin pyykinpesukin, ulkoistettu, mikä tietysti sekin tarjoaa työtä alueen yrittäjille.

Työntekijältä maaseudun pienyrityksessä vaaditaan kuitenkin paljon sopeutumista. Henkilöstökulujen säätely kun on yksi yrityksen tärkeimmistä selviytymiskeinoista asiakasmäärien vaihdellessa. Työntekijät olivat usein osa-aikaisia, jolloin heille oli sovittu minimityöaika kuukaudessa. Usein henkilökunta oli valmis myös joustamaan omaehtoisesti; suurin osa sovittaa työnsä aikoihin, jolloin hoivaa kaipaavia asiakkaita on paikalla eniten.

\section{Töissä kotona ja vapaa-ajalla}

Asiakastyön ja yksityiselämän raja on usein häilyvä. Tyypillisesti yrittäjä saattoi asua perheineen samassa pihapiirissä, tai jopa samoissa tiloissa, kuten perhekodeissa. Tarpeen vaatiessa yrittäjä ottaa tyynyn ja peiton mukaansa ja tulee nukkumaan tukea tarvitsevan asiakkaansa luokse.

Tätä ei kuitenkaan koettu ongelmaksi, sillä kyseessä oli itse valittu elämäntapa. Lyhyttä työmatkaa ja kodin läheisyyttä pidetään hyvänä asian, vaikka toisaalta asiakkaat ja työ on tarpeen pitää myös erillään. Tässä mielessä yrityksen kasvaminen ulkoisen työvoiman käyttöön onkin usein tarkoituksenmukaista. Tällöin yrittäjä pystyy järjestämään myös itselleen tilaisuuden omaan perheelämään ja irtautumiseen työn parista.

Hoivapalveluyritysten vetäjät olivat kaikki naisia. Yrittäjän puoliso tai tilan isäntä olivat usein mukana yritystoiminnassa. Esimerkiksi vanhusten hoivakodissa isäntä toimi talonmiehenä ja ratsastusterapiatallilla hevosen taluttajana terapiaratsastuksessa. Yrittäjän perhe onkin kiinteä osa yritystä niin saavana kuin antavanakin osapuolena 
Vanhusten hoivakotiyrittäjä korostaa, että ”Eri sukupolvet on tässä yhdessä. Sillä oli vanhuksille merkitystä ja sillä oli myös hirveen kehittävä hyvä merkitys mun omille lapsille...”

\section{Maatila ja maaseutu hoivayrityksen kilpailutekijänä}

Yrityksissä tunnistetaan maaseutuympäristön tuomat voimavarat, vaikka niitä ei aina aktiivisesti esille tuotaisikaan.

Vanhusten hoivakodeissa maaseutuympäristön terapeuttisuus oli tullut selkeästi esille. Suurimmalla osalla asiakkaista on maalaistausta ja vanhemmiten ihmisten ajatuskulku pyrkii suuntautumaan nykyisyydestä lapsuuteen ja nuoruuteen. Osa asiakkaista taas on kaupunkilaisia, jotka haluavat maalle vanhuudenpäivinään. Rauhallinen ja kaunis luonnonympäristö kohottaa mielialaa ja antaa mahdollisuuden hiljentyä. Turvallisessa ympäristössä on hyvä ulkoillakin. Maatilantöiden samoin kuin vuodenaikojenkin seuraaminen tuo vaihtelua hoivakodin arkirutiineihin. "Laiskatkin liikkujat on helppo motivoida mukaan kun mennään katsomaan esimerkiksi lähistöllä laiduntavia hevosia”. Ulkona nähdyt asiat tuovat virikkeitä keskusteluun vanhusten kanssa ja liikunta ylläpitää fyysistä kuntoa.

Lapsille maatilan laaja piha ja pellot mahdollistavat vapaan liikkumisen. Lapset voivat yhdessä aikuisten kanssa työskennellä pihalla ja puutarhassa, ja hoitaa eläimiä. Mahdollisuus työskentelyyn yhdessä aikuisten kanssa on uutta monelle kaupungista tulevalle, esimerkiksi perhekotiin sijoitetulle lapselle.

Päiväkodissa vuodenaikojen kiertokulku on tärkeää. Keväällä kylvetään ja istutetaan, ja syksyllä kootaan satoa. Vuodenaikojen juhlahetket värittävät arkipäivää. Lapsilla on myös mahdollisuus kehittää fyysisiä ja sosiaalisia taitojaan metsissä ja rannoilla retkeillen sekä majoja rakennellen.

Niin lasten kasvamisessa kuin vajaakuntoisten kuntoutumisessakin päivittäiset rutiinit ja vastuuseen oppiminen ovat tärkeitä tavoitteita. Esimerkiksi kanojen päivittäistä hoitoa käytettiin osana mielenterveyspotilaiden kuntoutusta.

Ratsastusterapiassa ulkoilu on puolestaan oleellinen osa kuntoutusta. Ratsun avustuksella liikuntakyvytön tai apuvälineillä liikkuva asiakas pääsee laajentamaan elinpiiriään esimerkiksi metsäympäristöön. Sekä ympäristöllä että hevosella on tärkeä vaikutus asiakkaan mielialaan. Erityisesti lasten kohdalla on huomattu, kuinka terapian pakollisuus ja omat liikunnalliset ongelmat unohtuvat ja asennoituminen kuntoutukseen muuttuu. Asiakkaan motivoituminen ratsastusterapiaan on yleensä hyvä, koska "siinä tehdään oikeita asioita”. Sosiaalipedagogisessa hevostoiminnassa mukaan tulee myös aikuisen läsnäolo ja talliyhteisö, jolla on merkittävä asema nuorten kasvun tukemisessa ja ongelmien voittamisessa. Talliyhteisö antaa selkeät rajat, hevonen ja työ tuovat vastuullisuuden.

Ratsastusterapialla on Suomessa jo pitkät perinteet ja se kuuluu KELA:n korvaamaan kuntoutukseen. Sen sijaan eläinavusteisen kuntoutuksen kuten sosiaalipedagogisen hevostoiminnan markkinoinnissa on ollut vaikeuksia. Kuntoutuksen vaikuttavuutta on vaikea osoittaa, koska siihen ei ole olemassa mitään mittareita. Mittareiden kehittäminen vaatisi puolestaan eläinavusteisen toiminnan fyysisten, psyykkisten ja sosiaalisten tekijöiden nykyistä parempaa tuntemista.

\section{Johtopäätökset}

Maaseutu maatiloineen voi tarjota hoivayrittäjyyteen omat vahvuutensa, jonka kautta monen lapsen, vanhuksen, vammaisen ja mielenterveyskuntoutujan elämänlaatua ja hyvinvointia voidaan parantaa. 
Yksilöllisyys ja valinnanvapaus ovat osa elämäntapaamme. Niin se voi olla myös heillä, joilla on jotain henkisiä tai fyysisiä rajoitteita omassa elämässään.

Tässä tutkimuksessa haastatellut yrittäjät ovat kaikki oman alansa edellä kävijoitä ja uudistajia. He ovat ihmisiä, jotka ovat muuttaneet oman unelmansa ammattitaidoksi ja liiketoiminnaksi. Sosiaalisten innovaatioiden, niin kuin tässäkin, omaksuminen ja leviäminen toimialalle on kuitenkin riippuvaista monesta yhteiskunnan asettamasta reunaehdosta. Tiedonpuute on yksi keskeisimmistä rajoitteista. Tietoa puuttuu heiltä, jotka suunnittelevat tämän alan yritystoimintaa, samoin kuin heiltä, jotka päättävät hoivaa, hoitoa ja kuntoutusta tarvitsevien ihmisten sijoittamisesta.

Tutkimusta tarvitaan edelleen, jotta maaseutuympäristön, eläinkontaktien ja työn vaikutus ihmisen hyvinvointiin voidaan paremmin hahmottaa ja käyttää näitä elementtejä terapeuttisesti. Niin ikään tarvitaan tuotteistamista, jotta palveluiden tarjoajat ja potentiaaliset asiakkaat löytävät toisensa.

\section{Kirjallisuus}

Anttonen, A., Sointu, L. 2007. Hoivapolitiikka muutoksessa. Julkinen vastuu pienten lasten ja ikääntyneiden hoivasta 12:ssa Euroopan maassa. Stakes. Helsinki.

Kaarakainen, M., Kinnunen, B., Pirttimäki, S., Huotari, N., Kinnunen, Oili. Hoivayrittäjyyden tulevaisuudet. Futura 2/2006: 25-45.

Kansallinen projekti... 2004. Kansallinen projekti terveydenhuollon tulevaisuuden turvaamiseksi. Hoidon saatavuus ja jonojen hallinta. Sosiaali- ja terveysministeriön työryhmämuistioita 2003:33. Sosiaali- ja terveysministeriö, Helsinki.

Lilja, T., Yli-Viikari, A. 2007. Tulevaisuuden hoivamaatilalta saadaan terveyttä ja hyvinvointia. Helsingin sanomat 27.3.2007. Vieraskynä.

Partanen U, Lilja T, Kurppa S \& Soini K 2006. Farming for Health in Finland. In: Hassink J., van Dijk Majken (toim.) Farming for Health. Green -Care farming Across Europe and the United States of America. Springer Netherlands. s. 135-146.

Stakes 2007. Tilastot ja rekisterit. Yksityiset sosiaalipalvelut. www.stakes.fi/FI/tilastot/aiheittain/Sosiaalipalvelut/yksityisetsosiaalipalvelut.htm 